University of Nebraska - Lincoln

DigitalCommons@University of Nebraska - Lincoln

Nebraska Cooperative Fish \& Wildlife Research Nebraska Cooperative Fish \& Wildlife Research Unit -- Staff Publications

2009

\title{
Seasonal Patterns of Song Structure Variation in a Suboscine Passerine
}

Bruce A. Robertson

University of Montana - Missoula

Joseph J. Fontaine

University of Arizona, jfontaine2@unl.edu

Elizabeth Loomis

University of Montana - Missoula

Follow this and additional works at: https://digitalcommons.unl.edu/ncfwrustaff

Part of the Other Environmental Sciences Commons

Robertson, Bruce A.; Fontaine, Joseph J.; and Loomis, Elizabeth, "Seasonal Patterns of Song Structure Variation in a Suboscine Passerine" (2009). Nebraska Cooperative Fish \& Wildlife Research Unit -- Staff Publications. 76.

https://digitalcommons.unl.edu/ncfwrustaff/76

This Article is brought to you for free and open access by the Nebraska Cooperative Fish \& Wildlife Research Unit at DigitalCommons@University of Nebraska - Lincoln. It has been accepted for inclusion in Nebraska Cooperative Fish \& Wildlife Research Unit -- Staff Publications by an authorized administrator of DigitalCommons@University of Nebraska - Lincoln. 


\title{
Seasonal Patterns of Song Structure Variation in a Suboscine Passerine
}

\author{
Bruce A. Robertson, ${ }^{1,3,4}$ Joseph J. Fontaine, ${ }^{2}$ and Elizabeth Loomis ${ }^{1}$
}

\begin{abstract}
Studies of song and its function in suboscine passerines are rare. We examined spatial and temporal variation in song structure in a wild population of Olive-sided Flycatchers (Contopus cooperi) and tested among hypotheses explaining this variation. Repeatable variation in song type was observed both within and among individuals. More than $10 \%$ of territorial males expressed atypical song types, i.e., permutations of sequential missing and repeated elements of the typical adult song. Atypical songs were predominantly expressed by unpaired males independent of habitat type. A small fraction of males sang atypical song through the middle of the breeding season, but all males sang only stereotypical adult song by the end of the season. These results suggest the expression of atypical songs reflect protracted vocal development rather than evolution of new song types, geographic variation in song structure, or an extensive song repertoire in Olive-sided Flycatchers. Received 17 November 2008. Accepted 18 March 2009.
\end{abstract}

Suboscines comprise $\sim 20 \%$ (1,151 species) of the Order Passeriformes (Sibley and Monroe 1990), but studies of bird song and its functions have focused almost exclusively on oscines. Suboscines are characteristically incapable of song learning (Kroodsma 1984, but see Saranthan

\footnotetext{
${ }^{1}$ Avian Science Center, University of Montana, Missoula, MT 59812, USA.

${ }^{2}$ Sonoran Desert Research Station, University of Arizona, Tucson, AZ 85721, USA.

${ }^{3}$ Current address: W. K. Kellogg Biological Station, Michigan State University, 3700 East Gull Lake Drive, Hickory Corners, MI 49060, USA.

${ }^{4}$ Corresponding author; e-mail: roberba1@msu.edu
}

et al. 2007). Substantial variation in suboscine song structure exists and likely has important implications for evolution of suboscine breeding systems. Some suboscine species exhibit geographic variation in song structure (Lindell 1998, Sedgwick 2001, Isler et al. 2005). Others exhibit a repertoire of song types (Craig 1943, Kroodsma 1985, Smith and Smith 1996, Lein 2007) and, even in species with a single song type (e.g., Vermillion Flycatcher, Pyrocephalus rubinus), males can vary the length of a single structural component resulting in 'long' or 'short' songs (Ríos-Chelén and Garcia 2007). Males express different song types when associating with a female or interacting with competing neighboring males. Thus, as in oscine passerines, different aspects of song expression should vary in importance throughout the breeding season (Smith and Smith 1996, Ríos-Chelén and Garcia 2007, Sexton et al. 2007). However, a paucity of studies examining variation in structure of suboscine song remains a barrier to a clearer understanding of the frequency and extent of variation in song among suboscine species.

We investigated variation in song structure in the Olive-sided Flycatcher (Contopus cooperi) because reports of 'alternate song types' (Wright 1997 in Altman and Sallabanks 2000) suggest the existence of substantial extant variation, but the underlying source of this variation remains unclear. The Olive-sided Flycatcher is a migratory flycatcher in the family Tyrannidae (Sibley and Ahlquist 1990). The typical adult male song is a 


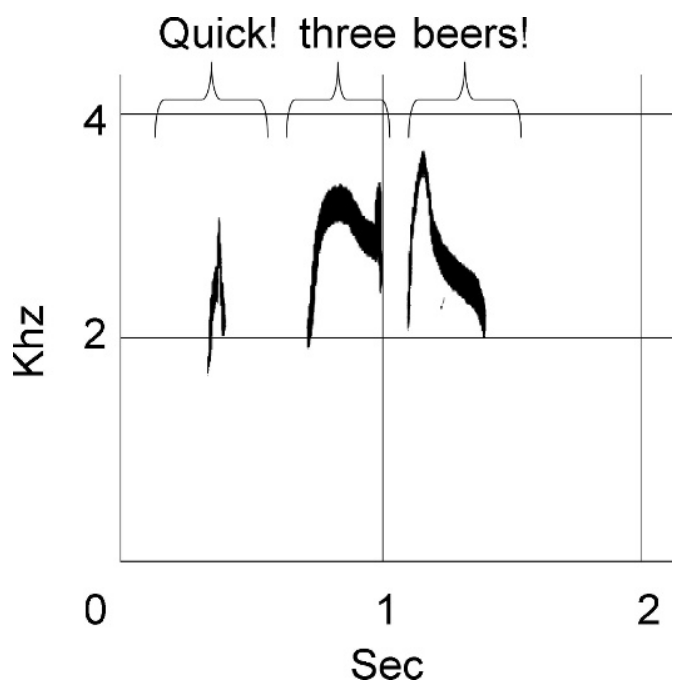

FIG. 1. Sonogram of typical adult song of Olive-sided Flycatcher with associated phonetics (reprinted with permission from The birds of North America).

loud three-note whistle popularly translated as "quick, three beers!" (Fig. 1), which can be detected from distances as great as $500 \mathrm{~m}$ (Brandy 2001). The first note is shorter, softer, and lower in pitch than the other two, which are strongly accented and drawn out (Altman and Sallabanks 2000). Variation in song structure in Olive-sided Flycatchers may reflect the expression of alternative song types by individuals or differences in song expression of different individuals or populations, and it may also arise from the existence of song fragments that are ephemeral precursors in the development of a stereotypical adult song type. Male suboscines commonly produce a typical adult song by onset of their first breeding season (Kroodsma 1984, 1985; Kroodsma and Konishi 1991; Trainer et al. 2002), but a longer developmental period is possible and we considered a protracted vocal ontogeny as another potential explanation for variation in song structure. Our objective was to test among these alternative hypotheses by providing a detailed description of the extent of song variation within and among different individual Olive-sided Flycatcher populations, and how the song structure of individuals changed throughout the breeding season.

\section{METHODS}

This study was conducted in 2002 within two sites: a recently burned forest within the $29,000-$ ha Moose Fire which burned in the Flathead National Forest in $2001\left(48^{\circ} 32^{\prime} 43^{\prime \prime} \mathrm{N}, 114^{\circ} 33^{\prime}\right.$ $\left.41^{\prime \prime} \mathrm{W}\right)$ and an unburned forest on Plum Creek Timber Company lands and selectively harvested

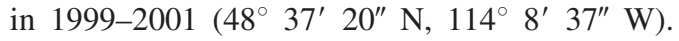
Sites were separated by $32 \mathrm{~km}$ and a branch of the Flathead Mountain range. We surveyed for male flycatchers from mid-May (before arrival of any male) through early August and characterized individual male vocalizations during three 12-day sampling sessions: (1) post-arrival (21 May-2 Jun), (2) mid-breeding season (23 Jun-4 Jul) and (3) late-breeding (25 Jul-5 Aug). We located nesting attempts within the study area (Robertson and Hutto 2007) and mapped territories of individual males by spot-mapping vocalizing and counter-vocalizing territorial males (Ralph et al. 1993). Territory locations and estimated sizes were based on a minimum of 23 locations of an individual singing, counter-singing, or having other aggressive interactions with other territorial males and were marked on a high-resolution aerial photo of the study area (1:700). Individual nests and conspicuous landmarks throughout the study area were located using handheld Global Positioning System units and placed on georectified handheld maps to improve the accuracy of mapped locations of males. Flycatcher territories were large ( $>20 \mathrm{ha}$ ) at both sites and separated by at least $100 \mathrm{~m}$ (B. A. Robertson, unpubl. data). Territories were considered occupied if a male was detected singing over three consecutive days during the arrival period, attending an incubating female, and/or feeding young or observed defending the area over at least five consecutive visits during the breeding season (Robertson and Hutto 2007).

Each territory was visited twice during each of the three sampling periods prior to $1100 \mathrm{hrs}$ MDT. We approached focal males detected at their first audible vocalization to within $50 \mathrm{~m}$, well within the effective detection distance for this species (300 m, Brandy 2001), and documented song type by ear, recording the order and number of each song syllable (quick, three, beers) for a minimum of 5 min of continuous song. We kept males constantly in sight during all observations. Sampling by ear may limit our ability to detect subtle differences in tone or volume, but the highly discernable nature of each syllable, along with the simple and highly repeatable structure of each song, enabled us to easily differentiate among distinct song types. We characterized 
males singing atypical songs as those that were repeatedly missing one of the three syllables characteristic of adult song (quick, three beers!) or those in which syllables were repeated in sequence (e.g., 'quick, three!', 'three beers!', “quick, three beer-beers!”, “quick, quick, three beers!" or "'beers!'). Vocalization of the lone syllable "quick" is commonly used as an alarm call (Altman and Sallabanks 2000), and this syllable was not considered a song fragment. We considered a male to be expressing an alternative song only if he consistently sang a minimum of 10 sequential repetitions of a single atypical song type during both of our visits during the same sampling period.

We estimated habitat-specific pairing success based on the percentage of territorial males that were observed in close association with a female on at least three separate visits or were observed in association with a nesting attempt. We compared the frequency of males with atypical song types between habitats at the onset of breeding using a Chi-square test of independence and used $\alpha=0.05$ as the level of statistical significance.

\section{RESULTS}

We identified 66 territorial males from the two habitat types (burn: $n=31$; harvest: $n=35$ ), of which $13.5 \%$ (9 males) consistently presented atypical song types within at least one sampling session. Males' song types represented permutations of sequential and repeated elements of the typical adult song ('"quick, three!", $n=5$; “"quick, three, beer-beers!", $n=1$; " "quick, quick, three beers!', $n=2$; 'three beers!", $n=1$ ) and individuals were not observed to sing more than one 'type' of atypical song. Males singing typical song were not heard to revert back to expressing even a single bout of atypical song. No males were observed singing different song types (atypical or typical) within a sampling session, but seven of the nine males observed singing atypical song types at the onset of the breeding season had switched to stereotypical adult song by the second sampling session. The remaining two males were also singing only stereotypical adult song by the final sampling session.

The frequency of males singing atypical song types was significantly higher in the burned habitat (burned, $n=7$; harvested, $n=2$; $\left.\chi^{2}{ }_{1}=3.971, P=0.050\right)$. Overall, seasonal pairing success was $71 \%$ (47 of 66 ), yet males singing atypical song types during the first sampling session were less likely to find a mate (Fisher's exact test, $P=0.009$ ); only two of nine males singing atypical songs were paired, both of which were in the harvested study area.

\section{DISCUSSION}

Repeatable variation in song type was observed among individuals with $>10 \%$ of the population expressing atypical song types, and within individuals, despite a consistent preference for an atypical song type by some individuals well into the breeding season. All males sang stereotypical adult songs by the end of the season. That atypical songs were predominantly expressed by unpaired males, and that all males sang the same song type by the end of the season suggests the expression of atypical songs may reflect protracted vocal development, rather than evolution of new song types, geographic variation in song structure, or an extensive song repertoire in Olivesided Flycatchers. Previous research on suboscines has demonstrated that atypical song types are not uncommon at the onset of the breeding season (Craig 1943). Assuming oscines and suboscines experience similar processes of song crystallization (e.g., Kroodsma 1984, 1985; Kroodsma and Konishi 1991), occasional atypical vocalizations likely result from variation in the timing of the crystallization of adult song. Our results illustrate an unusually delayed progress in song crystallization compared to previous studies in the wild (e.g., Craig 1943) with some males singing atypical song types into the latter half of the breeding season.

Our results support protracted vocal ontogeny as the most parsimonious explanation for variation in song structure in these populations, but we did not directly assign age or mark individual birds which may limit our ability to exclude alternative explanations. There is good reason to believe individuals expressing atypical songs are likely younger and/or subordinate individuals. First, atypical song types were most commonly expressed in burned habitats. Olive-sided Flycatchers prefer selectively harvested forests, and younger and/or subordinate birds are generally relegated to burned forests (Robertson and Hutto 2007). Second, pairing success was significantly lower among individuals with alternative songs, as is common among younger and/or subordinate passerines (reviewed by Saether 1990). The generally low pairing success in this system may 
reflect slow colonization of burned forests for which creation is a generally rare and unpredictable event. Last, no males were found expressing alternative songs anywhere in the study area at the end of the breeding season which suggests that yearlings eventually developed stereotypical songs or that subordinate individuals were displaced by dominant individuals expressing stereotypical songs.

Our results illustrate that many individuals lack either the ability or motivation to produce all three syllables of the adult song at the beginning of the breeding season, which could have significant fitness consequences due to reduced pairing success. The coarse structural differences we observed may be accompanied by more subtle differences in song structure among or within individual males and among geographically more distant areas. An improved library of information on variation in suboscine song structure and ontogeny in the wild is essential if we are to develop a more synthetic understanding of the mechanisms governing vocal development and the function of song in this poorly understood avian clade.

\section{ACKNOWLEDGMENTS}

We thank the Mazamas Foundation for funding, Dave Brown for his tireless field work, and D. E. Kroodsma and an anonymous reviewer for their insights. This work complied with the current laws governing animal research in the United States.

\section{LITERATURE CITED}

Altman, B. And R. Sallabanks. 2000. Olive-sided Flycatcher (Contopus cooperi). The birds of North America. Number 502.

BRANDY, P. M. 2001. A hierarchical analysis of Olive-sided Flycatcher habitat use in a managed landscape. Thesis. Humboldt State University, Arcata, California, USA.

Craig, W. 1943. The song of the Wood Pewee Myiochanes virens Linnaeus: a study of bird music. New York State Museum Bulletin 334:105.

Isler, M. L., P. R. Isler, AND R. T. Brumfield. 2005. Clinal variation in vocalizations of an antbird (Thamnophilidae) and implications for defining species limits. Auk 122:433-444.

KroodsmA, D. E. 1984. Songs of the Alder flycatcher (Empidonax alnorum) and Willow Flycatcher (Empidonax traillii) are innate. Auk 101:13-24.
Kroodsma, D. E. 1985. Development and use of two song forms by the Eastern Phoebe. Wilson Bulletin 97:2129.

Kroodsma, D. E. AND M. KonISHI. 1991. A suboscine bird (Eastern Phoebe, Sayornis phoebe) develops normal song without auditory feedback. Animal Behavior 42:477-487.

LEIN, M. R. 2007. Patterns of dawn singing by Buffbreasted Flycatchers. Journal of Field Ornithology 78:343-351.

LINDELL, C. 1998. Limited geographic variation in the vocalizations of a neotropical furnariid, Synallaxis albescens. Wilson Bulletin 110:368-374.

Ralph, C. J., G. R. Geupel, P. Pyle, T. E. Martin, and D. F. Desante. 1993. Handbook of field methods for monitoring landbirds. USDA, Forest Service, General Technical Report PSWGTR-144. Pacific Southwest Research Station, Albany, California, USA.

Ríos-Chelén, A. A. AND C. M. GARCIA. 2007. Responses of a suboscine bird during playback: effects of different song variants and breeding period. Behavioral Processes 74:319-325.

Robertson, B. A. AND R. L. HutTo. 2007. Is selectively harvested forest an ecological trap for Olive-sided Flycatchers? Condor 109:109-121.

SAETHER, B. E. 1990. Age-specific variation in reproductive performance of birds. Current Ornithology 7:251283.

Saranathan, V. S., D. Hamilton, G. V. N. Powell, D. E. Kroodsma, AND R. O. Prum. 2007. Genetic evidence supports song learning in the Three-wattled Bellbird Procnias tricarunculata (Cotingidae). Molecular Ecology 16:3689-3702.

SEDGWICK, J. A. 2001. Geographic variation in the song of Willow Flycatchers: differentiation between Empidonax traillii adastus and E. t. extimus. Auk 118:366379.E

Sexton, K., M. T. Murphy, L. J. Redmond, And A. C. DolAN. 2007. Dawn song of Eastern Kingbirds: intrapopulation variability and sociobiological correlates. Behaviour 144:1273-1295.

Sibley, C. G. AND J. E. Ahlquist. 1990. Phylogeny and classification of birds: a study in molecular evolution. Auk 108:990-994.

Sibley, C. G. AND B. L. Monroe JR. 1990. Distribution and taxonomy of birds of the world. Yale University Press, New Haven, Connecticut, USA.

Smith, W. J. AND A. M. SMith. 1996. Vocal signaling of the Great Crested Flycatcher, Myiarchus crinitus (Aves, Tyrannidae). Ethology 102:705-723.

Trainer, J. M., D. B. McDonald, AND W. A. Learn. 2002. The development of coordinated singing in cooperatively displaying Long-tailed Manakin. Behavioral Ecology 13:65-69. 